\title{
Lake sedimentation as an agent of postglacial transformation of interfluves and fluvial landscapes of the Borisoglebsk Upland, Central European Russia
}

\author{
Ekaterina V. Garankina ${ }^{1}$, Vladimir R. Belyaev ${ }^{2}$, Ilya G. Shorkunov ${ }^{3}$, Yuliya V. Shishkina ${ }^{1}$, \\ Pavel V. Andreev ${ }^{4}$, and Elena D. Sheremetskaya ${ }^{1}$ \\ ${ }^{1}$ Department of Geomorphology and Paleogeography, Faculty of Geography, Lomonosov Moscow State \\ University, Moscow, 119991, Russia \\ ${ }^{2}$ Laboratory for Soil Erosion and Fluvial Processes, Faculty of Geography, Lomonosov Moscow State \\ University, Moscow, 119991, Russia \\ ${ }^{3}$ Department of Soil Geography and Evolution, Institute of Geography, Russian Academy of Sciences, \\ Moscow, 119017, Russia \\ ${ }^{4}$ Institute of Earth Sciences of Saint-Petersburg State University, St Petersburg, 199034, Russia
}

Correspondence: Ekaterina V. Garankina (evgarankina@gmail.com)

Published: 1 August 2019

\begin{abstract}
Borisoglebsk Upland is considered an example of a secondary upland plain in the marginal zone of the last Middle Pleistocene glaciation. Moraine hills and kames were reworked by glaciofluvial processes and incised by small fluvial forms later. Its postglacial surface drift cover is regularly defined as an undivided complex of mantle loams of dominantly subaerial origin with characteristic cryogenic features and remnants of paleosols. However, some previous studies suggest that lake sedimentation played an important role in the postglacial history of the Borisoglebsk Upland. This paper presents results of a detailed investigation of postglacial sedimentary cover of the eastern part of the Borisoglebsk Upland aimed to reconstruct the co-evolution of surface deposits, soil cover and geomorphic landscapes since degradation of the last Middle Pleistocene glaciation about $150 \mathrm{ka}$ (MIS-6). The study is essentially based on a comprehensive lithological, pedological and geocryological description of postglacial deposits in cores (hand or machine-driven) and open sections, systematic sampling for grain size analysis and selective sampling for ${ }^{14} \mathrm{C}$ absolute dating and monoliths structural examination. The results indicate that most of the surface drifts in this feature consists of stratified lacustrine deposits. Their Late Pleistocene age is stratigraphically confined by the underlying paleosols and incorporated peats of the Mikulino interglacial age (MIS-5) and several organic-rich layers within the lake sequence ${ }^{14} \mathrm{C}$ dated to the Middle Valdai interstadial (MIS-3). Overlying mantle loams and colluvial deposits with cryogenic features and low organic matter content those facially substitute lacustrine sediments were attributed to the Late Valdai stadial (MIS-2). After the Mid-Holocene stabilization, relatively thin colluvial cover identified by the increased amount of organic matter also deposited. We conclude that lacustrine sedimentation is the primary Late Pleistocene agent that transformed the initial glacial topography and most characteristic type of lithodynamics of the eastern Borisoglebsk Upland.
\end{abstract}




\section{Introduction}

The eastern part of the Borisoglebsk Upland is located near the Nero Lake in Central European Russia and has long been an attraction for paleogeographers and archeologists who conduct research to reconstruct the natural environment and human settling histories. However, the detailed evolution of this landscape during the postglacial period remains unclear. In particular, little is known about the formation of interfluve areas and smaller elements of the fluvial network. Classically this region is regarded as a secondary upland plain in the marginal zone of the last Middle Pleistocene glaciation (Moscow Age, MIS-6) (Semenov et al., 1972; Astakhov et al., 2016). Topography of this feature include moraine hills and kames reworked by glaciofluvial activity and partly dissected by small valleys and gullies. Surface drift cover overlying glacial tills is often defined as an undivided complex of mantle loams. A complete genetic classification of these silty and sandy loams with characteristic cryogenic features as well as remnants of paleosols is currently lacking. Typically not exceeding a depth of 2-3 m, they are reported across several parts of European Russia and Europe and are correlated with loesses of the southerly regions (Velichko et al., 2006). Many researchers propose this feature is predominantly of subaerial origin formed under periglacial conditions that included a combination of aeolian, cryogenic and shallow pool sedimentation processes (Makeev et al., 2017). However, geological map of Quaternary deposits (O-37-XXVIII, scale $1: 200000$ ) indicates that this upland consists of up to $8 \mathrm{~m}$ of mantle loams (Semenov et al., 1972). Maximum relative elevation between the highest interfluve and the Nero Lake level is about $111 \mathrm{~m}$ (Fig. 1b). However, local topographic ranges are mostly within 5-20 m, which suggests the thickness of surface loams to be close to the relative elevation of local landforms. Accordingly, detailed information on its origin is an important key to further elucidate evolution of the geomorphic landscape.

Individual studies suggest that lacustrine sedimentation played an important role in the postglacial history of the Borisoglebsk Upland (Kvasov, 1975; Rusakov and Sedov, 2012). Our recent detailed analysis of these postglacial deposit cover shows that a significant part is composed of lake sediments that are unrelated to the main Nero Lake terraces (93-120 m a.s.l.). Moreover, these lacustrine deposits not only cover the most recent glacial tills but they also play an important part in the modern topography of both lower interfluvial surfaces and upper parts of gullies and small valleys in elevation range of $150-180 \mathrm{~m}$ a.s.l.

The present paper provides new insights regarding the lithology, paleopedology and relic cryogenic deformation of the Late Pleistocene surface drifts located on the eastern macroslope of the Borisoglebsk Upland. Accordingly, the results of this investigation are employed to reconstruct the co-evolution of surface deposits and geomorphic landscapes
Table 1. Sampling protocol of the 2016-2019 field campaigns.

\begin{tabular}{lrr}
\hline Type of analysis & $\begin{array}{r}\text { Number of } \\
\text { samples collected }\end{array}$ & $\begin{array}{r}\text { Number of } \\
\text { samples analyzed }\end{array}$ \\
\hline Grain size & 434 & 150 \\
LOI & 338 & 83 \\
14 C dating & $25 / 22$ & $3 / 0$ \\
(AMS/scintillation) & & \\
Core monoliths & 53 & 25 \\
\hline
\end{tabular}

of the study area since degradation of the last Middle Pleistocene glaciation about $150 \mathrm{ka}$.

\section{Materials and methods and study site description}

The study is based on a comprehensive lithological, pedological and geocryological description of postglacial deposits in cores (hand or machine-driven) and open sections followed by characterizing the grain size and loss on ignition of bulk samples and in monoliths, inspecting of microstructures and selective ${ }^{14} \mathrm{C}$ dating. Core positions were obtained by post-processing differential GNSS survey with Leica GX 1200 base-rover complex with typical horizontal error $< \pm 2 \mathrm{~cm}$ and vertical $< \pm 10 \mathrm{~cm}$. Topography was analyzed by means of both visual field descriptions, GNSS profiling, conventional geomorphic mapping and the GIS-based morphometric analysis of open-source satellite imagery (DigitalGlobe/GeoEye (Google Earth), IRS and LANDSAT (Yandex Maps), global satellite radar DEMs (SRTM and ALOS 3D), land planning topographic maps $(1: 10000)$ and aerial photography obtained by UAVs DJI Phantom III and IV).

Grain size analysis involved standard sample preparation (Konert and Vandenberghe, 1997), dry sieving of coarser fractions $(>100 \mu \mathrm{m})$ by the Fritsch Analysette 3 PRO mechanical sieve shaker and laser diffractometry of the finer component $(<100 \mu \mathrm{m})$ by the Fritsch Analysette Nanotek 22 at the Laboratory of Experimental and Dynamic Geomorphology and Paleogeography, MSU, Russia (Table 1). Organic and chemical carbon content was measured by ignition at 500 and $900^{\circ} \mathrm{C}$ (A5TM D 2974-87, 1993; Heiri et al., 2001). Structural organization and textural composition of sedimentary and soil (paleosol) bodies were examined using macro-photography in reflected light (macromorphology for more than $230 \mathrm{~m}$ and mesomorphology for about $100 \mathrm{~m}$ of cores and sections). Organic-rich layers were collected for ${ }^{14} \mathrm{C}$ dating using the AMS technique at the Laboratory of Radiocarbon Dating and Electronic microscopy, Institute of Geography RAS, Russia, and Center for Applied Isotope Studies, University of Georgia, USA, and scintillation technique at the Radiocarbon Dating Laboratory, Institute of Environmental Geochemistry, National Academy of Sciences, Ukraine (Table 2). 


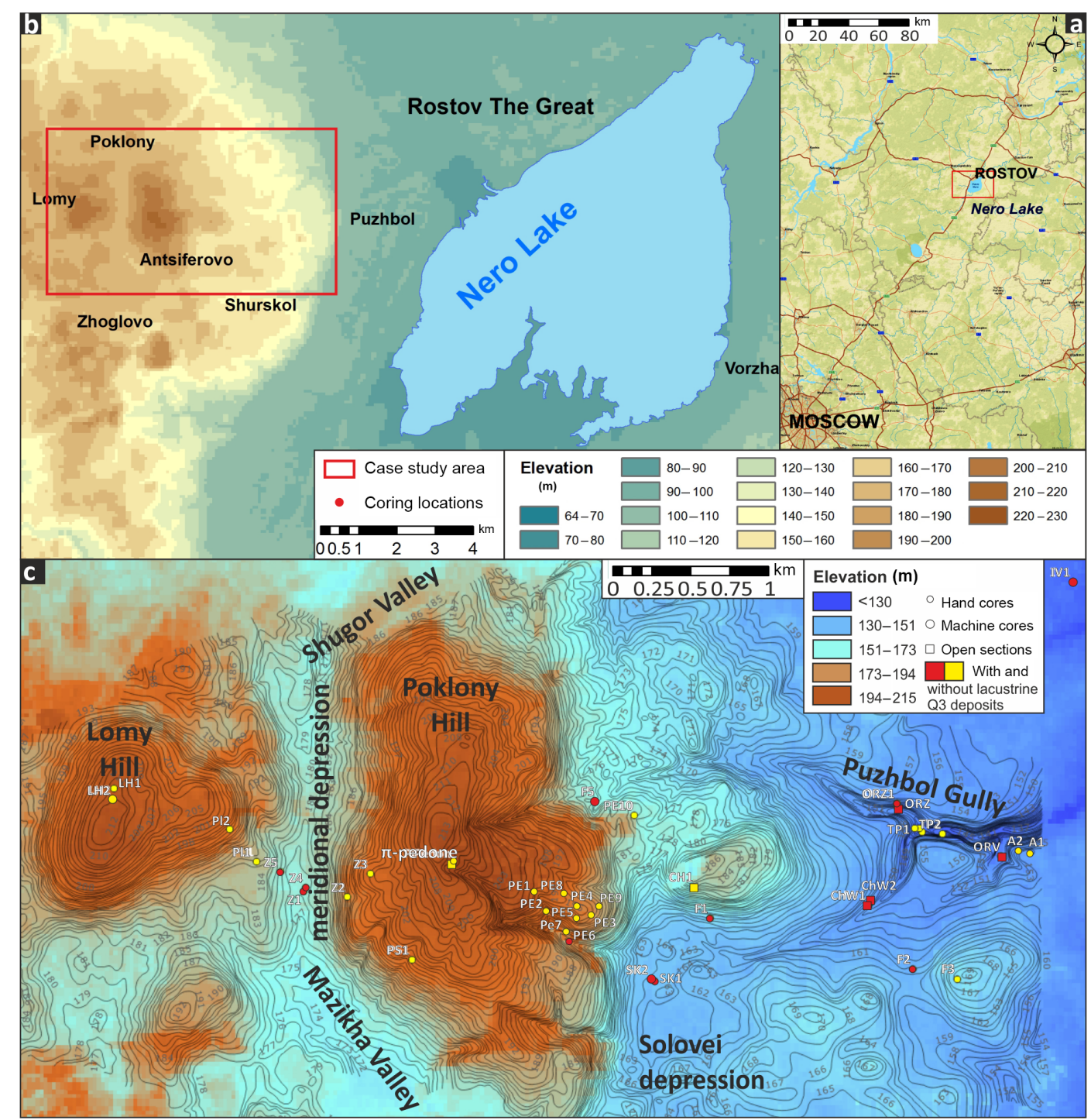

Figure 1. Position of the case study area: (a) at the Central Russian Plain (source: (C) Google global topography, infrastructure and settlements), and (b) at the eastern Borisoglebsk Upland (source: (CALOS 3D $30 \mathrm{~m}$ ); (c) its detailed topography based on 1 : 10000 land planning maps (contour interval $1 \mathrm{~m}$ ).

Borisoglebsk Upland is located in the center of the Russian Plain about $200 \mathrm{~km}$ to the northeast from Moscow City, in the southern part of the Yaroslavl Region (Fig. 1a). Historically this landscape was considered as a secondary Moscow glacial plain (MIS-6) moderately reworked by superimposed, primarily glaciofluvial and fluvial, processes (Novskij, 1975; Semenov et al., 1972; Sudakova et al., 2013). In the study area (Fig. 1b), most elevated (up to $214 \mathrm{~m}$ a.s.l.) interfluves and regional base level (Nero Lake, $93 \mathrm{~m}$ a.s.l.) are closely placed determining a specific rolling-stepped structure of local topography. It is incised by small valleys and associated gully systems.

The pedolithostratigraphy of the study area located north of Shurskol and Puzhbol settlements was investigated from interfluves down to the Nero Lake terraces (the lowest studied section at $105 \mathrm{~m}$ a.s.l.). Below $180 \mathrm{~m}$ a.s.l., the gentle slope is composed of thick (up to $10 \mathrm{~m}$ ) complex deposits overlying the irregular surface of the Middle Pleistocene glacial till. Its structure was examined in 35 hand (up to $8 \mathrm{~m}$ deep, core diameter $3 \mathrm{~cm}$ ) and 9 machine (up to $20 \mathrm{~m}$ deep, core diameter 8 and $10 \mathrm{~cm}$ ) cores (total depth $>250 \mathrm{~m}$ ) as well as 9 pits, quarries or natural exposures (Fig. 1c). Several sites previously studied by Semenov et al. (1972), Lavrushin, Chistyakova (2001), and Rusakov et al. (2015) were further investigated by our research group (Shishkina et al., 2019). Sampling strategy was modified to separate initial patterns of lithological composition and superimposed cryo- and pedofeatures. 
Table 2. $\mathrm{AMS}^{14} \mathrm{C}$ dating results from the meridional depression key site and corresponding calibrated ages.

\begin{tabular}{|c|c|c|c|c|c|c|c|c|}
\hline \multirow[t]{2}{*}{ No. } & \multirow[t]{2}{*}{ Depth/altitude, $\mathrm{m}$} & \multirow[t]{2}{*}{ Core } & \multirow[t]{2}{*}{ Layer } & \multirow[t]{2}{*}{ Material } & \multirow[t]{2}{*}{ Lab number } & \multirow[t]{2}{*}{${ }^{14} \mathrm{C}, \mathrm{yr} \mathrm{BP}( \pm 1 \sigma)$} & \multicolumn{2}{|c|}{ cal yr BP } \\
\hline & & & & & & & $2 \sigma$ & Median \\
\hline 1 & $0.54-0.56 / 176.9$ & $\mathrm{Z} 4$ & $\begin{array}{l}\text { upper layer of } \\
\text { cover beds }\end{array}$ & TOC & IGAN $_{\text {AMS }} 6289^{\mathrm{a}}$ & $3630 \pm 20$ & $3877-4062$ & 3941 \\
\hline 2 & $4.13-4.22 / 173.8$ & $\mathrm{Z1}$ & base of alluvium & Plant rs. & IGAN $_{\text {AMS }} 6290^{\mathrm{a}}$ & $40680 \pm 310$ & $43535-44864$ & 44228 \\
\hline 3 & $5.52-5.56 / 173.8$ & $\mathrm{Z} 5$ & $\begin{array}{l}\text { lower part of } \\
\text { lacustrine unit }\end{array}$ & TOC & IGAN $_{\text {AMS }} 6288^{\mathrm{a}}$ & $32450 \pm 155$ & $35958-36750$ & 36335 \\
\hline 4 & $0.96-1.02 / 160.8$ & SK2 & $\begin{array}{l}\text { gyttja layer in } \\
\text { slope deposits }\end{array}$ & TOC & $\mathrm{Ki}-19676^{\mathrm{b}}$ & $5190 \pm 60$ & $6179-5754$ & 5955 \\
\hline 5 & $5.50-5.55 / 156.3$ & SK2 & $\begin{array}{l}\text { peat lens in the middle } \\
\text { part of lacustrine unit }\end{array}$ & TOC & $\mathrm{Ki}-19671^{\mathrm{b}}$ & $31440 \pm 300$ & $36007-34746$ & 35336 \\
\hline
\end{tabular}

${ }^{\text {a }}$ Results were calibrated using ${ }^{14} \mathrm{C}$ date calibrating programs CALIB REV7.1.0 and ${ }^{\mathrm{b}} \mathrm{OxCal}$ v4.3.2.

\section{Results and discussion}

The interfluve topography of the eastern Borisoglebsk Upland is comprised of two types of hill structures with strikingly different morphology. Interfluves at an elevation of $180-215 \mathrm{~m}$ a.s.l. are represented by two large $(25-50 \mathrm{~m}$ relative elevation, basal diameter up to $1.5-3.0 \mathrm{~km}$ ) flat-topped hills with comparatively steep and in some places gradually stepped, slopes. They are separated by the glaciofluvial depression stretched in almost longitudinal direction and connecting headwaters of the two modern small valleys (Fig. 1c). 17 cores and an open section at the highest hilltop show widespread distribution of thick ( $>10 \mathrm{~m}$ ) contrastingly stratified clayey loams and sands covered by less clearly finelaminated silty loams $1-2.5 \mathrm{~m}$ deep. That allowed us to propose a glaciolacustrine hypothesis of origin of such larger hills. They were formed by material from lakes initially located on top or inside of the melting Moscow glacier superimposed on the glacial till surface - kame-like mechanism of formation. Lower interfluves surrounding the base of these larger hills exhibit some evidence of the dead ice topography. Groups of shallow rounded depressions and low hillocks with relative elevation not exceeding 4-5 m (socalled kettle holes topography) are isometric or slightly elongated (Garankina et al, 2018).

The morphology and geological structure of the lower interfluves (180-130 ma.s.l.) between the basis of the highest hills and the upper Nero Lake terraces were examined in 24 cores and 4 exposures on gully sides. At all locations, Moscow glacial tills are covered by a pronounced finegrained layer (silty to clayey loams with fine sandy enrichments) with clearly visible and texturally contrast multiscale lamination (up to five levels of laminae thickness, Fig. 2). Mottled color alternations (rusty yellow to pinkish or blueish grey to brownish dark grey) are indicators of $\mathrm{FeO}_{3}$ and $\mathrm{FeO}_{2}$ forms and organic matter that are typical of deposits created in standing water. Organic-rich lenses (peats, plant detritus or paleosols) and visible signs of relic pedogenesis (desiccation pores and planes) clearly identify the interruptions in lacustrine sedimentation. Simultaneously levels with welldeveloped cryogenic deformations (Belyaev et al., 2019) or traces of slope erosion material (subangular clayey clasts, Fig. $2 \mathrm{~g}$ ) point towards the periods of shallow lake levels.

Upwards, sediments tend to lighten in color with amplifying yellowish hue and lacking of any organic matter. Lamination is also less contrast and clear. With more or less distinct contact, they are substituted by deposits variegated in color. Those patchy or lenticular rather than regularly laminated textures with highly contrasting lithology interspersed with sands and gravels suggest their primary subaerial origin due to intensified solifluction and slope erosion and distinct trend of lakes to cease existing. Such phenomenon was described for the Central European region as periglacial cover beds (Kleber and Terhorst, 2013; Reinhardt-Imjela et al., 2018). We suggest a potential to correlate the intermediate and upper layers of cover beds with the upper lacustrine facies with strong colluvial income and overlying slope deposits of the study area.

The highest upper boundary of Late Pleistocene lacustrine deposits (177.6 m a.s.1.) was in Z5 core and its lowest base (133.4 $\mathrm{m}$ a.s.1.) - in Iv1 core (Fig. 1b). Hence, the elevation range where Late Pleistocene lacustrine deposits were observed (beyond the limits of Nero Lake terraces) is almost $45 \mathrm{~m}$. In general, they are found in almost all exposures below $180 \mathrm{~m}$ a.s.l. except for the hilltops those are composed of 2-4 $\mathrm{m}$ of very fine subaerial deposits - silty loams to clays (core F3, A1).

SK2 core (161.8 $\mathrm{m}$ a.s.1.) with the thickest Late Pleistocene lacustrine deposits is located at the bottom of the Solovev depression (Fig. 1c). More than $6 \mathrm{~m}$ of fine-grained material (dominantly sandy to clayey loam) with some input from adjacent slope gullies (sand to small gravel particles) alternates with and is underlain by peat layers. Plant macrofossils emerge in almost the entire volume of the core ampli- 


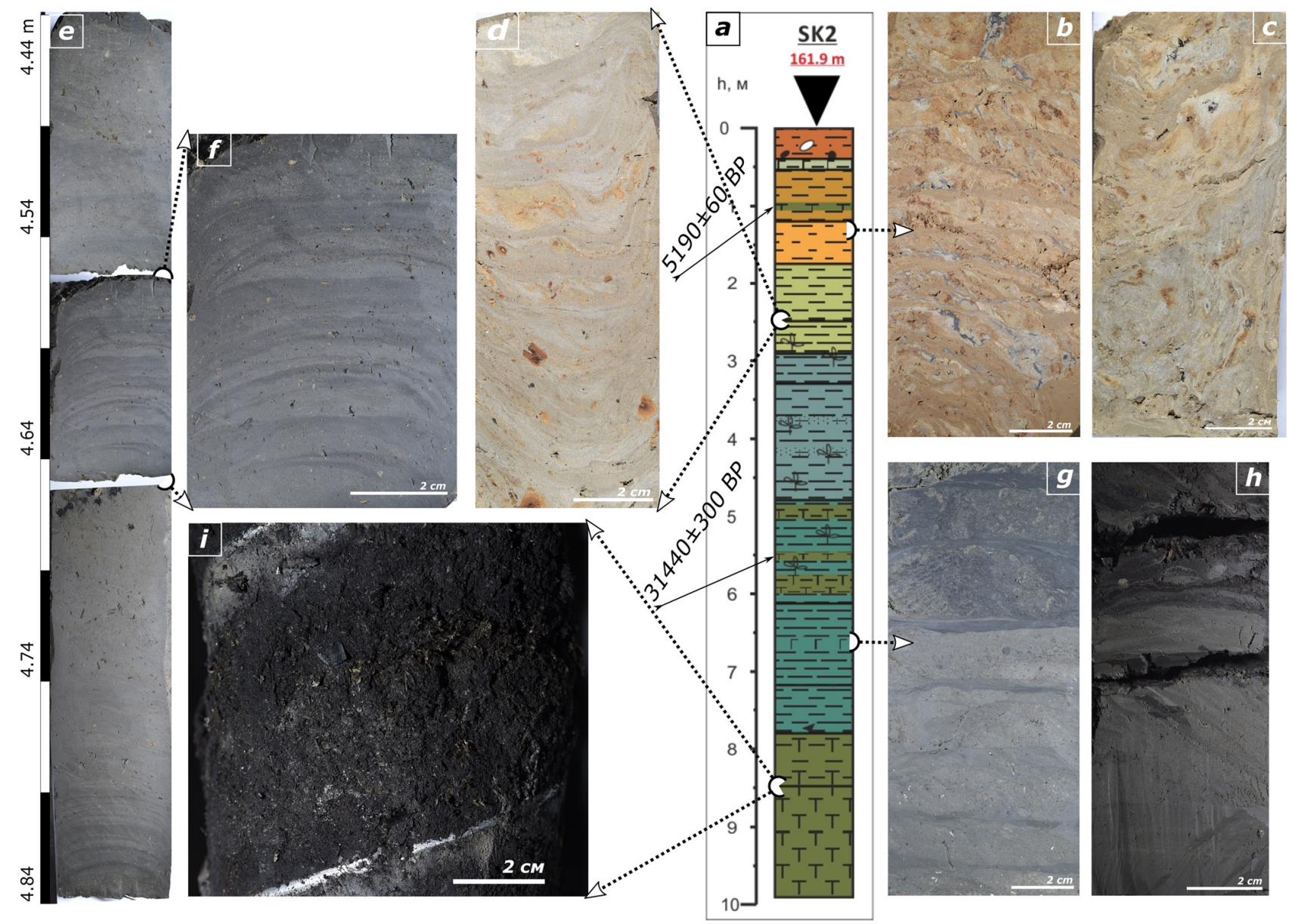

Figure 2. General lithostratigraphy and structure of postglacial sediments of the study site: (a) lithostrtigraphic column of SK2 core; (b) upper sedimentary layer - colluvium with irregular laminae-mottled structure and highly contrast texture; (c) fragment of cryogenic structure with subvertical laminae in colluvium; (d) regular cm-scale lamination in the upper lacustrine unit; slight cryogenic deformations, carbonate sand grains and ferrugineous nodules infilling fragments of plant detritus; (e) dm-scale stratification and (f) $\mathrm{cm}$ - and mm-scale laminae in the intermediate lacustrine unit; (g) $\mathrm{cm}$-scale lamination with subangular clayey clasts and (h) fragments of dense peaty laminae in the lower lacustrine unit; (i) laminated basal peats.

fying in quantity downwards (Fig. 2). The lacustrine stratum splits into three distinctively different units. The upper approximately $1 \mathrm{~m}$ of light pale grey (with clearly visible mottling) clayey-silty loam without visible organic input (Fig. 2d) underlies the yellowish colluvial deposits with clear cryogenic structure evidencing slope wash, solifluction and cryoturbations (Fig. $2 \mathrm{~b}-\mathrm{c}$ ), The lower $>5 \mathrm{~m}$ of grey to dark-grey silty-clayey loam to clay with intermittent more sandy and gravelly layers (slope gully inputs) divide into intermediate and lower units. The former is most clearly finelaminated (Fig. 2e-f), indicating deeper and calmer lake environments. The latter is dark-brown-grey with contrast stratification due to peat and plant detritus lenses $1-10 \mathrm{~cm}$ thick (Fig. 2g-h), representing changes of lake to peat bog sedimentation regime during dryer periods. Basal peats (Fig. 2i) likely correlate with the layers attributed to the Mikulino interglacial in adjacent locations (Rusakov et al., 2015). The
${ }^{14} \mathrm{C}$ date $31440 \pm 300$ years BP (Ki-19671, Table 2) separating the lower and intermediate lacustrine units, recognizes that the former accumulated under milder conditions of the Early to Middle Valdai. A thin gyttja lens in overlying colluvium dates to $5190 \pm 60$ years $\mathrm{BP}$ (Ki-19676). This confines the deposition of the upper and intermediate lacustrine units to the second half of the Valdai. Particularly the upper fossilless unit was likely formed in cold Late Valdai periglacial environments with increasing role of slope processes input.

Lacustrine sedimentation was occasionally interrupted by increased fluvial activity represented by erosive contacts and lenses of sand with fine gravels (Z1, Z4, ChW1, ChW2) or completely ceased under the influence of incision-infill cycles (ORV). Radiocarbon ages of buried organic-rich lenses from lacustrine and overlying fluvial facies in adjacent cores $\mathrm{Z1}, \mathrm{Z4}, \mathrm{Z5}$ at $173.8 \mathrm{~m}$ a.s.l. were acquired (Table 2). The results display lower lacustrine unit deposition succeeded by 
the secondary incision that likely occurred no later than the Middle Valdai (MIS-3) (Shishkina et al., 2019). Colluvial deposits and mantle loams at the top of the sedimentary sequences are typically ascribed to the Late Valdai periglacial period (MIS-2) (Velichko et al., 2004). However, pronounced organic-rich lenses (Table 2, dates 1 and 4) indicate that at least the upper $0.6 \mathrm{~m}$ formed under temperate conditions of the second half of the Holocene. Thus, two sets of ${ }^{14} \mathrm{C}$ dates obtained at different elevations (cores SK2 and Z-series) show good correspondence, suggesting regional scale of revealed lacustrine sedimentation trends.

Our study provides new evidence for an idea initially proposed by Rusakov and Sedov (2012) that observed surface drift layers traditionally interpreted as polygenetic cover loams (Semenov et al., 1972; Makeev et al., 2017) are more likely represented by lake deposits. The Late Pleistocene age of that lacustrine sequence is confirmed by its stratigraphic position: (1) overlying the eroded Middle Pleistocene till surface (MIS-6), at places with remnants of the Mikulino interglacial texturally-differentiated soils (Shishkina et al., 2019) or ephemeral peaty soils dated by U-Th method as MIS-5e (Rusakov et al., 2019); (2) occasionally underlain by peats interpreted as Early Mikulino by several spore-pollen analyses (Semenov et al., 1972) and U-Th dated as MIS5 (Rusakov et al., 2019); (3) incorporating several organicrich layers with newly obtained ${ }^{14} \mathrm{C}$ dates (Table 2) those are in accordance with the Middle Valdai ages reported by Rusakov et al. (2015, 2019). These humic layers probably reflect short-term pedogenesis on periodically dried lake bottoms and gully sides (Shishkina et al., 2019); (4) gradually disappearing plant macrofossils and organic carbon content in upper unit of the lacustrine sequence together with its upward change into typical mantle loams or colluvial deposits with clear cryogenic structures implicate scarce vegetation and severe periglacial conditions with increased cryogenic, slope wash and solifluction activity during the Late Valdai. In general, the observed lacustrine sedimentation can be considered prolonged and continuous through the majority of the Late Pleistocene with limited interruptions by dryer episodes or, at certain locations, fluvial incisions.

Certain lithological variability observed between cores and sections does not conceal the fact of their general similarities, including clear alternation of structural organization and textural composition of lacustrine strata reflecting the same variability of the lithodynamic (and possibly climatic) signals through time. Those could be considered as typical and most common sedimentary sequences of the Late Pleistocene lithogenesis of the eastern Borisoglebsk Upland. This observation contrasts with most of the published simplified models of polygenetic subaerial origin of mantle loams (Makeev et al., 2017). Lacustrine sediments of the Late Pleistocene age are present on all studied interfluve surfaces below $180 \mathrm{~m}$ a.s.l. and in infilled parts of the fluvial network. Their thickness is comparable with typical local relative elevations of the initial glacial topography that appears to be substantially smoothened if not entirely flattened by the lake infills. It means that the observed lacustrine sedimentation, together with cryogenic processes, as evident in several open sections (Belyaev et al., this issue), is the main agent of the Late Pleistocene landscape transformation in the study area.

More detailed genetic interpretation and absolute age evaluation of lacustrine deposits found on most of the lower interfluve surfaces and in gully side exposures is required. Two hypotheses can be advanced for further study. A long-term high water level stand of a jointed lake system inundating a series of depressions along the southern limit of the last Late Pleistocene ice cover from the Plecsheevo and Nero Lakes towards the Galich Lake may have occurred as proposed by Kvasov (1975) and Rusakov and Sedov (2012). However, the source of such recent waterbody of enormous volume is difficult to explain because meltwater generated during the Late Pleistocene glaciation should have been even less than that of the Middle Pleistocene glaciers. An alternative explanation may be an existence of a series of small local and relatively shallow bodies of standing water formed in numerous depressions of initial glacial topography (Antonov, 1998; Sheremetskaya et al., 2012) that periodically dried and were gradually filled by sediment from catchments slopes and peat formation. Even though this question has yet been left open, our data on grain size and organic content distribution and instrumental age determination do not support an existence of large-scale glacially induced lake. It rather speculates for the continuous lacustrine sedimentation in small isolated basins under significantly changing environmental conditions.

\section{Conclusions}

1. Detailed analysis of the eastern macroslope of the Borisoglebsk Upland suggests that most of the surface drift materials initially interpreted as polygenetic mantle loams were likely formed by continuous postglacial lacustrine deposition. Main arguments of such genetic interpretation are the dominance of fine-grained fractions; clear and texturally contrast multiscale lamination (up to five levels of laminae thickness); mottled colors typical for standing water environment. The Late Pleistocene age of that lacustrine sedimentation is stratigraphically evidenced by the Mikulino (Eemian) interglacial paleopedofeatures on the eroded surface of underlying Moscow glacial till and several organic-rich layers (paleosol humus horizons, peat, gyttja and plant debris lenses) in the lacustrine sequence dated to the Mikulino (MIS-5) interglacial and Middle Valdai (Middle Weichselian) interstadial (MIS-3).

2. Despite certain lithological variability observed between cores and sections, particularly those located on different elevations and in varying paleogeomorphic positions, general structural organization and textural composition of lacustrine stratum commonly ex- 
hibits clearly evident alternation through time reflecting the same lithodynamic (and, possibly climatic) signals. Those can, therefore, be considered as typical and most common sedimentary sequences of the Late Pleistocene at the eastern Borisoglebsk Upland. This conclusion is certainly novel in contrast with most of the previously published models of dominantly subaerial polygenetic origin of mantle loams.

3. The observed lacustrine sediments of the Late Pleistocene age systematically occur both on all studied interfluve surfaces below $180 \mathrm{~m}$ and in buried parts of the fluvial network. Its thickness is comparable or, at places, even exceeds local relative elevations. It means that the lacustrine sedimentation was the main and yet underestimated agent of the Late Pleistocene topography transformation in the study area.

Data availability. For more information about the used data please contact the corresponding author Ekaterina V. Garankina (evgarankina@gmail.com).

Author contributions. All co-authors took part in field working and sampling. EVG, EDS and YVS carried out grain size and LOI analyses. IGS and PVA performed structural and palaeopedogenic analyses of both geological exposures and monoliths. VRB, EVG and IGS designed cartographic materials processing and artwork and prepared the manuscript with contributions from all co-authors.

Competing interests. The authors declare that they have no conflict of interest.

Special issue statement. This article is part of the special issue "Land use and climate change impacts on erosion and sediment transport". It is a result of the ICCE Symposium 2018 - Climate Change Impacts on Sediment Dynamics: Measurement, Modelling and Management, Moscow, Russia, 27-31 August 2018.

Acknowledgements. Special gratitude is to Andrey V. Dolgikh (IG RAS) for the ${ }^{14} \mathrm{C}$ dates calibration and a large number of the MSU students and staff, colleagues from the IG RAS and St Petersburg State University and friends who took part in fieldworks and helped with associated logistics.

Financial support. This research has been supported by the Russian Foundation for Basic Research (project 18-05-01118), the Department of Geomorphology and Paleogeography, Faculty of Geography, (GA no. AAAA-A16-11632810089-5) and the IG RAS (GA no. 0148-2019-0006).

\section{References}

ASTM D 2974-87: Standard Test Methods for Moisture, Ash, and Organic Matter of Peat and Other Organic Soils, USGA Green Section Record, March/April, 31-33, 1993.

Antonov, S. I.: Pleistocene lacustrine lithomorphogenesis at the southeastern Moscow region limits, in: History of Pleistocene lakes of the Eastern European Plain, Saint Petersburg, Nauka, 282-290, 1998 (in Russian).

Astakhov, V., Shkatova, V., Zastrozhnov, A., and Chuyko, M.: Glaciomorphological Map of the Russian Federation, Quaternary Int., 420, 4-14, 2016.

Belyaev, V. R., Semochkina, A. E., Streletskaya, I. D., Lisova, A. D., Garankina, E. V., Shorkunov, I. G., and Lugovoy, N. N.: Relic periglacial features and their impact on modern soil redistribution processes on cultivated slopes of the European Russia, PIAHS, submitted, 2019.

Garankina, E. V., Belyaev, V. R., Shorkunov, I. G., Andreev, P. V., Verlova, T. A., Shishkina, Yu. Vl., and Bondar, A. I.: Evolution of the Borisoglebsk Upland interfluves over the last 150000 years (Marginal zone of Moscow Glaciation, central part of Russian Plain), in: Practical Geography and XXI Century Challenges. International Geographical Union Thematic Conference, Moscow, Russia, 4-6 June 2018, Conf. Book, Part 1, 180-187, 2018.

Heiri, O., Lotter, A. F., and Lemcke, G.: Loss on ignition as a method for estimating organic and carbonate content in sediments: reproducibility and comparability of results, J. Paleolimnol., 25, 101-110, 2001.

Kleber, A. and Terhorst, B. (Eds.): Mid-Latitude Slope Deposits (Cover Beds), in: Developments in Sedimentology, 66, 1st Edn., Elsevier Science, 302 pp., 2013.

Konert, M. and Vandenberghe, J.: Comparison of laser grain size analysis with pipette and sieve analysis: a solution for the underestimation of the clay fraction, Sedimentology, 44, 523-535, 1997.

Kvasov, D. D.: Late Quaternary History of Large Lakes and Inland Seas of Eastern Europe, Leningrad, Nauka, 279 pp., 1975 (in Russian).

Lavrushin, Yu. A. and Chistyakova, I. A. (Eds.): Problems in the Stratigraphy of Quaternary Deposits and Paleogeography of the Yaroslavl Volga Basin: Proceedings of the International Symposium, GEOS-Press, Moscow, 2001 (in Russian).

Makeev, A., Kust, P., Lebedeva, M., Rusakov, A., Terhorst, B., and Yakusheva, T.: Soils in the bipartite sediments within the Moscow glacial limits of the Russian Plain: Sedimentary environment, pedogenesis, paleolandscape implication, Quatern. Int., 501, 147-173, https://doi.org/10.1016/j.quaint.2017.09.017, 2019.

Novskij, V. A.: Pleistocene of Yaroslavl Volga region, Moscow, Nauka, 236 pp., 1975 (in Russian).

Reinhardt-Imjela, C., Maerker, K., Schulte, A., and Kleber, A.: Implications of hydraulic anisotropy in periglacial cover beds for flood simulation in low mountain ranges (Ore Mountains, Germany), Die Erde, 149, 86-101, https://doi.org/10.12854/erde2018-374, 2018.

Rusakov, A. and Sedov, S.: Late Quaternary pedogenesis in periglacial zone of northeastern Europe near ice margins since MIS 3: Timing, processes, and linkages to landscape evolution, Quaternary Int., 265, 126-141, 2012. 
Rusakov, A., Nikonov, A., Savelieva, L., Simakova, A., Sedov, S., Maksimov, F., Kuznetsov, V., Savenko, V, Starikova, A., Korkka, M., and Titova, D.: Landscape evolution in the periglacial zone of Eastern Europe since MIS5: proxies from paleosols and sediments of the Cheremoshnik key site (Upper Volga, Russia), Quaternary Int., 365, 26-41, https://doi.org/10.1016/j.quaint.2014.09.029, 2015.

Rusakov, A., Sedov, S., Sheinkman, V., Dobrynin, D., Zinovyev E., Trofimova, S., Maximov, F., Kuznetsov, V., Korkka, M., and Levchenko, S.: Late Pleistocene paleosols in the extra-glacial regions of Northwestern Eurasia: Pedogenesis, post-pedogenic transformation, paleoenvironmental inferences, Quaternary Int., 501, 174-192, https://doi.org/10.1016/j.quaint.2018.03.020, 2019

Semenov, A. A, Tsukurova, A. M., Kvyatkovskaya, G. N., and Kuznetsov, V. K.: Geological map of Quaternary deposits, Scale $1: 200000$. Moscow series. Sheet O-37-XXVIII. Explanatory text, VSEGEI Publ., 1972 (in Russian).

Sheremetskaya, E. D., Borisova, O. K., and Panin, A. V.: Planation of Moscow glaciation periglacial zone during postglacial epoch, Geomorfologiya, 1, 92-106, 2012 (in Russian).
Shishkina, Yu. Vl., Garankina, E. V., Belyaev, V. R., Shorkunov, I. G., Andreev, P. V., Bondar, A. I., Potapova, V. I., and Verlova, T. A.: Postglacial Incision-Infill Cycles at the Borisoglebsk Upland: Correlations between Interfluve Headwaters and Fluvial Network, Int. Soil Water Conserv. Res., 7, 184-195, https://doi.org/10.1016/j.iswcr.2019.02.001, 2019.

Sudakova, N. G., Antonov, S. I., and Vvedenskaya, A. I.: Structure of glacial marginal zones in the center of the East European Plain, Bulletin of Moscow University, Series 5, Geography, 6, 55-61, 2013 (in Russian).

Velichko, A. A., Morozova, T. D., Nechaev, V. P., Rutter, N .W., Dlusskii, K. G., Little, E. C., Catto, N. R., Semenov, V. V., and Evans, M. E.: Loess/paleosol/cryogenic formation and structure near the northern limit of loess deposition, East European Plain, Russia, Quaternary Int., 152-153, 14-30, https://doi.org/10.1016/j.quaint.2005.12.003, 2006. 